\title{
PENGARUH METODE PEMBELAJARAN PQRST TERHADAP TINGKAT PEMAHAMAN KONSEP MATEMATIKA SISWA
}

\author{
${ }^{1}$ Rakha Pradestya, ${ }^{2}$ Ana Setiani, M.Pd \\ ${ }^{12}$ Program Studi Pendidikan Matematika, Fakultas Keguruan dan Ilmu Pendidikan, Universitas \\ Muhammadiyah Sukabumi \\ 1rakha.a196@gmail.com \\ 2ana.setiani.math@gmail.com
}

\begin{abstract}
ABSTRAK
Ide penelitian ini muncul dari fenomena di sekolah tentang tingkat kemampuan matematika siswa yang relatif rendah. Khususnya di kelas IX. Hal ini terjadi karena beberapa faktor. Salah satunya adalah kesulitan siswa dalam memahami masalah dalam sebuah soal. Penelitian ini bertujuan untuk mencari tahu pengaruh dari metode pembelajaran Preview, Question, Rewrite, Solve, Test. Penelitian ini juga mencari tahu apakah metode pembelajaran PQRST dapat meningkatkan kemampuan pemahaman matematika siswa kelas IX di SMPN 3 Kota Sukabumi pada materi Pola, Barisan, dan Deret. Sampel yang diambil dalam penelitian ini adalah siswa kelas IX di SMPN 3 Kota Sukabumi. Di mana diambil dua kelas, yaitu kelas IX F dan IX G yang masing-masing kelasnya berjumlah 30 siswa. Pengumpulan data diambil menggunakan instrumen berupa lembar kerja siswa yang terdiri dari 5 soal pilihan ganda dan 5 soal uraian. Instrumen terlebih dahulu diuji cobakan kepada 8 siswa kelas IX di SMPN 3 Kota Sukabumi yang dipilih secara acak serta diuji validitas dan kelayakan soalnya. Metode penelitian yang dilakukan adalah metode kuantitatif. Sampel tidak berasal dari populasi yang berdistribusi normal dan memiliki varians yang berbeda. Maka dari itu, uji statistik yang digunakan adalah Uji U Mann-Whitney guna mencari tahu pencapaian kelas mana yang lebih baik, apakah kelas IX F yang tidak diberi perlakuan metode Preview, Question, Rewrite, Solve, Test. atau kelas IX G yang diberi perlakuan metode Preview, Question, Rewrite, Solve, Test.. Hasil penelitian ini menunjukkan bahwa pencapaian kelas IX G tidak lebih baik dari kelas IX F. Ini menunjukkan bahwa metode pembelajaran Preview, Question, Rewrite, Solve, Test tidak memberi peningkatan terhadap hasil belajar siswa, sehingga pemahaman konsep matematika siswa kelas IX di SMPN 3 Kota Sukabumi pada materi Pola, Barisan, dan Deret tidak meningkat.
\end{abstract}

Kata Kunci: Metode PQRST, pemahaman konsep matematika siswa, Pola Barisan dan Deret

\section{PENDAHULUAN}

Penelitian ini dilakukan atas hasil obsaervasi di mana tingkat pemahaman konsep matematika siswa yang masih terbilang rendah, dilihat dari hasil belajar siswa yang masih rendah. Tingkat pemahaman konsep matematika siswa sangatlah penting bagi siswa itu sendiri karena dengan memiliki tingkat pemahaman konsep matematika yang tinggi, siswa dapat memcahkan masalah di kehidupan seharihari terkait dengan matematika. Khususnya pada materi Pola, Barisan, da Deret sebagai materi yang digunakan pada siswa dalam penelitian ini.
Dalam hal ini, penulis melakukan penelitian tentang pengaruh salah satu metode pembelajaran, yaitu metode pembelajaran PQRST (Preview, Question, Rewrite, Solve, Test). Yaitu metode pembelajaran yang termasuk ke dalam model konstruktivisme, di mana siswa membangun pengetahuan sendiri atas informasi yang didapat dari masalah, dan menentukan alternatif solusi gunakan memecahkan masalah tersebut. Dalam penelitian ini, penulis mengharapkan metode PQRST dapat meningkatkan kemampuan pemahaman konsep matematika siswa. Penelitian ini dilakukan untuk mencari tahu apakah metode pembelajaran PQRST dapat membantu meningkatkan pemahaman konsep matematika siswa. 
Penelitian ini dilakukan pertama kali dilakukan terhadap mata pelajaran matematika. Jadi, belum ada yang melakukan penelitian ini sebelumnya. Maka dari itu, penulis tertarik untuk mengankat judul penelitian ini.

\section{LANDASAN TEORI}

Metode PQRST adalah salah satu metode yang digunakan untuk menyelesaikan soal cerita. Metode ini diperkenalkan oleh Thomas, Robinson, dan H. Alan dalam buku mereka yang bertajuk "Improving Reading in Every Class". Metode PQRST diambil dari inisial prosedur pengerjaannya, yaitu:

\begin{tabular}{|c|c|}
\hline Langkah & Tujuan \\
\hline \multirow[t]{4}{*}{ Preview } & $\begin{array}{l}\text { 1. Apakah ide dasar dari } \\
\text { persoalan? }\end{array}$ \\
\hline & $\begin{array}{l}\text { 2. Variabel-variabel apa } \\
\text { yang terdapat dalam soal } \\
\text { ? }\end{array}$ \\
\hline & $\begin{array}{l}\text { 3. Apa saja yang diketahui } \\
\text { dan belum diketahui yang } \\
\text { terkait dengan persoalan? }\end{array}$ \\
\hline & $\begin{array}{l}\text { 4. Fakta-fakta apa yang } \\
\text { terdapat pada soal yang } \\
\text { dapat digunakan untuk } \\
\text { membantu } \\
\text { menuyelesaikan soal? }\end{array}$ \\
\hline \multirow[t]{2}{*}{ Question } & $\begin{array}{l}\text { 1. Apa yang ditanyakan ? } \\
\text { 2. Apa saja hal-hal yang } \\
\text { diketahui dari persoalan } \\
\text { itu? }\end{array}$ \\
\hline & $\begin{array}{l}\text { 3. Langkah selanjutnya } \\
\text { menentukan perkiraan } \\
\text { jawaban apa yang sesuai } \\
\text { dengan pertanyaannya. }\end{array}$ \\
\hline Rewrite & $\begin{array}{l}\text { Menerjemahkan } \\
\text { permasalahan ke } \\
\text { bentuk matematika }\end{array}$ \\
\hline Solve & Mencari solusi \\
\hline Test & $\begin{array}{llr}\text { Pemeriksaan } & \text { kembali hasil } \\
\text { penyelesaian } & & \text { untuk }\end{array}$ \\
\hline
\end{tabular}

\begin{tabular}{|l|lc|}
\hline & $\begin{array}{l}\text { meyakinkan } \\
\text { jawaban dari suatu persoalan }\end{array}$ \\
\hline
\end{tabular}

Pemahaman konsep matematika adalah kemampuan siswa dalam memahami, menafsirkan, mengolah informasi, dan merubah informasi dari verbal ke bentuk matematikanya. Siswa disebut memiliki pemahaman konsep matematika yang tinggi saat siswa dapat memecahkan permasalahan baik itu berupa soal biasa, maupun soal cerita. Siswa yang memiliki tingkat pemahaman konsep matematika tinggi dapat menjelaskan pula konsep yang dipahaminya.

\section{METODE PENELITIAN}

Metode penelitian yang digunakan adalah metode penelitian kuantitatif. Teknik mengumpulan data dilakukan dengan menggunakan instrumen berupa lembar kerja siswa dengan 5 soal pilihan ganda dan 5 soal uraian tentang materi Pola, Barisan, dan Deret. Sebelum menentukan statistik uji yang digunakan, instrumen terlebih dahulu dicek validitasnya meliputi validitas muka dilakukan oleh salah satu guru mtematika di MAN 1 Kota Sukabumi, dan validitas empiris. Setelah diuji validitas empirisnya, hasil koefisien korelasi dengan materi lain pada mata pelajaran matematika kelas 9 adalah cukup.

Setelah diuji validitasnya, lalu instrumen diuji cobakan kepada 8 siswa kelas 9 di SMPN 3 Kota Sukabumi yang diambil secara acak. Setelah didapat hasilnya, data yang didapat lalu dianalisis butir dari soal tersebut. Tingkat kesukaran tiap soal beragam. Untuk pilihan ganda, soal no. 1, 4, dan 5 memiliki tingkat kesukaran soal yang sedang. Sedangkan soal no. 2 dan 3 memiliki tingkat kesukaran yang rendah. Sedangkan untuk taraf daya beda, soal 1 dan 4 memiliki taraf daya beda yang sedang, soal no. 2 dan 3 memiliki taraf daya beda yang rendah, dan no. 5 memiliki taraf daya beda yang sangat rendah. Soal pilihan ganda memiliki tingkat reliabilitas yang tinggi. Untuk soal uraian, no. 6a memiliki tingkat kesukaran soal yang rendah, no. $6 \mathrm{~b}$ memiliki tingkat kesukaran soal yang tinggi, dan no. 7a-7c memiliki tingkat kesukaran soal sedang. Untuk 
reliabilitasnya, no. $6 a$ dan $6 \mathrm{~b}$ tidak signnifikan, dan no. 7a-7c signifikan.

Setelah instrumen dianalisis. Instrumen diberikan kepada masing-masing 30 siswa kelas A sebagai kelas tanpa perlakuan metode PQRST dan 30 siswa kelas $\mathrm{B}$ dengan perlakuan metode PQRST. Kelas A dan kelas B diberikan instrumen setelah melakukan pembelajaran tentang materi Pola, Barisan, dan Deret dengan menggunakan metodenya masing-masing selama kurang lebih satu bulan. Lalu masing-masing kelas diberikan ujian berupa mengerjekan instrumen yang telah dianalisis. Setelah data nilai siswa di masing-masing kelas didapatkan, data diolah untuk menentukan apakah data tersebut berasal dari populasi yang normal dan memiliki varians yang sama atau tidak. Ternyata data tidak normal dan varians dari dua kelas yang diteliti tidak homogen (sama). Karena datanya bersifat independen, tidak normal, dan tidak homogen, maka statistik uji yang digunakan adalah Uji U Mann-Whitney.

\section{HASIL DAN PEMBAHASAN}

Berikut adalah hasil pencapaian siswa masing-masing kelas:

Kelas A

\begin{tabular}{|c|c|c|c|}
\hline Siswa & Nilai & Ketuntasan & $\begin{array}{l}\text { Rata- } \\
\text { Rata }\end{array}$ \\
\hline 1 & 58 & $\begin{array}{l}\text { Tidak } \\
\text { Tuntas }\end{array}$ & \multirow{6}{*}{81,3333} \\
\hline 2 & 62 & $\begin{array}{l}\text { Tidak } \\
\text { Tuntas }\end{array}$ & \\
\hline 3 & 67 & $\begin{array}{l}\text { Tidak } \\
\text { Tuntas }\end{array}$ & \\
\hline 4 & 70 & $\begin{array}{l}\text { Tidak } \\
\text { Tuntas }\end{array}$ & \\
\hline 5 & 73 & $\begin{array}{l}\text { Tidak } \\
\text { Tuntas }\end{array}$ & \\
\hline 6 & 73 & $\begin{array}{l}\text { Tidak } \\
\text { Tuntas }\end{array}$ & \\
\hline
\end{tabular}

\begin{tabular}{|c|c|c|}
\hline 7 & 75 & Tuntas \\
\hline 8 & 75 & Tuntas \\
\hline 9 & 75 & Tuntas \\
\hline 10 & 75 & Tuntas \\
\hline 11 & 80 & Tuntas \\
\hline 12 & 80 & Tuntas \\
\hline 13 & 80 & Tuntas \\
\hline 14 & 80 & Tuntas \\
\hline 15 & 80 & Tuntas \\
\hline 16 & 80 & Tuntas \\
\hline 17 & 80 & Tuntas \\
\hline 18 & 80 & Tuntas \\
\hline 19 & 80 & Tuntas \\
\hline 20 & 82 & Tuntas \\
\hline 21 & 90 & Tuntas \\
\hline 22 & 90 & Tuntas \\
\hline 23 & 90 & Tuntas \\
\hline 24 & 90 & Tuntas \\
\hline 25 & 90 & Tuntas \\
\hline 26 & 90 & Tuntas \\
\hline 27 & 95 & Tuntas \\
\hline 28 & 100 & Tuntas \\
\hline 29 & 100 & Tuntas \\
\hline 30 & 100 & Tuntas \\
\hline
\end{tabular}


Kelas B

\begin{tabular}{|c|c|c|c|}
\hline Siswa & Nilai & Ketuntasan & $\begin{array}{l}\text { Rata- } \\
\text { Rata }\end{array}$ \\
\hline 1 & 60 & $\begin{array}{l}\text { Tidak } \\
\text { Tuntas }\end{array}$ & \multirow{19}{*}{84,5667} \\
\hline 2 & 70 & $\begin{array}{l}\text { Tidak } \\
\text { Tuntas }\end{array}$ & \\
\hline 3 & 70 & $\begin{array}{l}\text { Tidak } \\
\text { Tuntas }\end{array}$ & \\
\hline 4 & 70 & $\begin{array}{l}\text { Tidak } \\
\text { Tuntas }\end{array}$ & \\
\hline 5 & 70 & $\begin{array}{l}\text { Tidak } \\
\text { Tuntas }\end{array}$ & \\
\hline 6 & 75 & Tuntas & \\
\hline 7 & 80 & Tuntas & \\
\hline 8 & 80 & Tuntas & \\
\hline 9 & 80 & Tuntas & \\
\hline 10 & 80 & Tuntas & \\
\hline 11 & 80 & Tuntas & \\
\hline 12 & 82 & Tuntas & \\
\hline 13 & 82 & Tuntas & \\
\hline 14 & 82 & Tuntas & \\
\hline 15 & 82 & Tuntas & \\
\hline 16 & 90 & Tuntas & \\
\hline 17 & 90 & Tuntas & \\
\hline 18 & 90 & Tuntas & \\
\hline 19 & 90 & Tuntas & \\
\hline
\end{tabular}

\begin{tabular}{|l|l|l|}
\hline 20 & 90 & Tuntas \\
\hline 21 & 90 & Tuntas \\
\hline 22 & 90 & Tuntas \\
\hline 23 & 92 & Tuntas \\
\hline 24 & 93 & Tuntas \\
\hline 25 & 93 & Tuntas \\
\hline 26 & 93 & Tuntas \\
\hline 27 & 93 & Tuntas \\
\hline 28 & 100 & Tuntas \\
\hline 29 & 100 & Tuntas \\
\hline 30 & 100 & Tuntas \\
\hline
\end{tabular}

Berdasarkan data yang didapat, secara umum dapat disimpulkan bahwa kelas B yang diberlakukan metode pembelajaran PQRST lebih baik dari kelas A yang tidak diberlakukan metode pembelajaran PQRST, karena nilai rata-rata kelas B lebih tinggi dari kelas A. Namun hal ini belum menunjukkan bahwa penerapan metode pembelajarn PQRST dapat meningkatkan kemampuan pemahaman konsep matematika siswa, karena data perlu dianalisis. Data dianalisis menggunakan statistik Uji U Mann-Whitney dengan pendekatan Uji Z karena data masingmasing kelas lebih dari 20.

Berikut adalah tabel hasil analisis Uji $U$ Mann-Whitney:

\begin{tabular}{|r|r|r|r|}
\hline \multicolumn{1}{|l|}{ Kelas A } & Kelas B & \multicolumn{1}{|l|}{$\begin{array}{l}\text { Kelas } \\
\mathbf{A}^{\prime}\end{array}$} & $\begin{array}{l}\text { Kelas } \\
\mathbf{B}^{\prime}\end{array}$ \\
\hline 58 & 60 & 1 & 2 \\
\hline 62 & 70 & 3 & 7 \\
\hline 67 & 70 & 4 & 7 \\
\hline
\end{tabular}




\begin{tabular}{|c|c|c|c|}
\hline 70 & 70 & 7 & 7 \\
\hline 73 & 70 & 10,5 & 7 \\
\hline 73 & 75 & 10,5 & 14 \\
\hline 75 & 80 & 14 & 21,5 \\
\hline 75 & 80 & 14 & 21,5 \\
\hline 75 & 80 & 14 & 21,5 \\
\hline 75 & 80 & 14 & 21,5 \\
\hline 80 & 80 & 21,5 & 21,5 \\
\hline 80 & 82 & 21,5 & 31 \\
\hline 80 & 82 & 21,5 & 31 \\
\hline 80 & 82 & 21,5 & 31 \\
\hline 80 & 82 & 21,5 & 31 \\
\hline 80 & 90 & 21,5 & 40 \\
\hline 80 & 90 & 21,5 & 40 \\
\hline 80 & 90 & 21,5 & 40 \\
\hline 80 & 90 & 21,5 & 40 \\
\hline 82 & 90 & 31 & 40 \\
\hline 90 & 90 & 40 & 40 \\
\hline 90 & 90 & 40 & 40 \\
\hline 90 & 92 & 40 & 47 \\
\hline 90 & 93 & 40 & 49,5 \\
\hline 90 & 93 & 40 & 49,5 \\
\hline 90 & 93 & 40 & 49,5 \\
\hline 95 & 93 & 52 & 49,5 \\
\hline
\end{tabular}

\begin{tabular}{|c|c|c|c|}
\hline 100 & 100 & 55,5 & 55,5 \\
\hline 100 & 100 & 55,5 & 55,5 \\
\hline 100 & 100 & 55,5 & 55,5 \\
\hline $\begin{array}{l}\text { Rata-rata } \\
=81,33333\end{array}$ & $\begin{array}{l}\text { Rata-rata } \\
=84,56667\end{array}$ & & \\
\hline
\end{tabular}

Keterangan:

Kelas $\mathrm{A}^{\prime}=$ ranking kelas $\mathrm{A}$

Kelas B'= ranking kelas B

$\begin{array}{ll}\mathrm{UA}= & 590 \\ \mathrm{UB}= & 398 \\ \alpha & \mathbf{0 , 0 1} \\ \alpha / 2 & \mathbf{0 , 0 0 5} \\ \sum \mathbf{R A}= & \mathbf{7 7 5} \\ \sum \mathbf{R B}= & 967\end{array}$

\begin{tabular}{|r|r|r|}
\hline $\begin{array}{l}\text { Nilai } \\
\text { Yang } \\
\text { Sama }\end{array}$ & \multicolumn{2}{|l|}{$\begin{array}{l}\text { Banyaknya } \\
\text { Nilai }\end{array}$} \\
\hline 70 & 5 & 10 \\
\hline 73 & 2 & 0,5 \\
\hline 75 & 5 & 10 \\
\hline 80 & 14 & 227,5 \\
\hline 82 & 5 & 10 \\
\hline 90 & 13 & 182 \\
\hline 93 & 4 & 5 \\
\hline
\end{tabular}




\begin{tabular}{|l|l|r|}
\hline 100 & & \\
\hline & & 17,5 \\
\hline & Jumlah t & 462,5 \\
\hline
\end{tabular}

Dari hasil analisis data, didapat kesimpulan bahwa metode PQRST tidak dapat meningkatkan kemampuan konsep matematika siswa pada materi Pola, Barisan, dan Deret, walaupun rerata nilai dari kelas B lebih tinggi dari kelas A. Banyak faktor yang membuat metode PQRST tidak dapat meningkatkan kemampuan konsep matematika siswa. Faktor terbesarnya adalah prosedur pemecahan masalah menggunakan metode PQRST yang terlalu rumit, karena mesti melewati banyak sekali prosedur yang membuat siswa malah merasa lebih kesulitan dalam memecahkan masalah yang ada pada instrumen. Langkah yang sulit dilakukan oleh siswa pada metode pembelajaran PQRST ini adalah pada saat Preview, di mana siswa mesti menentukan variabel, ide dasar, dan hal yang diketahui. Siswa kesulitan pada saat Preview karena siswa belum mahir menentukan ide dasar pemecahan masalah. siswa pun tidak mengetahui apa itu variabel. Hal ini dapat terjadi karena siswa terbiasa mengerjakan permasalahan secara langsung.

\section{SIMPULAN}

Dari pemaparan dan hasil analisis di atas, perlakuan metode pembelajaran PQRST pada pembelajaran matematika di materi Pola, Barisan, dan Deret tidak memberikan peningkatan yang signifikan terhadap kemampuna pemahaman konsep matematika siswa. Adapun rekomendasi dari peneliti untuk para guru matematika:

1. Kemampuan menentukan variabel dan ide dasar pemecahan masalah pada siswa harus lebih diasah dan dilatih lagi

2. Karena metode pembelajaran PQRST pada penelitian ini tidak memberikan peningkatan, maka dari itu berilah perlakuan metode pembelajaran lain yang diharapkan mampu meningkatkan kemampuan pemahaman konsep matematika siswa

\section{DAFTAR PUSTAKA}

Abin, Syamsudin. (2003). Psikologi Pendidikan. Bandung: PT Rosada

Harja, Media. Pemahaman Konsep Pembelajaran Matematika dengan Pendekatan

Kontruktivisme. 10 April 2018. Https://mediaharja.blogspot.co.i d/2011/11/pemahaman-konsephtml

Herdian. Kemampusn Pemahaman Matematika. 10 April 2018. Https://herdy07.wordpress.com/ 2010/05/27/kemampuanpemahaman-matematis/

Kesumawati, Nila. 92008). Pemahaman Konsep Matematika dalam Pembelajaran Matematika. Palembang : FKIP ProgramStudi Pendidikan Matematika Universitas PGRI Palembang

Lukman, Hamidah Suryani. (2007). Statistika Terapan Dasar. Bekasi: Nuraeni

Siti, Sugiarti. Peningkatan Keterampilan menyelesaikan Soal Cerita Melalui Metode Peer Tutoring Pada Siswa Kelas V SDN Pandowan, Kulon Progo. 11 April 2018.

Https://journal.umy.ac.id/index. php/cope/article/viewFile/10789 $\underline{18114}$

Sugiono. (2016). Metode Penelitian Kuantitatif, Kualitatif dan $R \& D$. Bandung: Alpabeta

Wirda. (2011). Meningkatkan Hasil Belajar Matematika Pada Soal Cerita dengan Menggunakan Metode Preview Question Read Store Test Siswa Kelas IVSDN 016 Ganting Kecamatan Solo Kabupaten Kampar. Pekanbaru: Universitas Islam Negeri Sultan Syarif Kasim Riau 